\title{
My dad and progressive supranuclear palsy (PSP)
}

\author{
Heather Angus-Leppan (1) 1,2
}

\begin{abstract}
'Department of Neurology, Royal Free Hospital, London, UK ${ }^{2}$ Epilepsy Unit, Insitute of Neurology, University College London Hospitals NHS Foundation Trust, London, UK
\end{abstract}

\section{Correspondence to} Dr Heather Angus-Leppan, Neurology, Royal Free Hospital, London NW3 2QG, UK: heather.angus-leppan@nhs. net

Accepted 25 January 2020

\section{Check for updates}

(C) Author(s) (or their employer(s)) 2020. No commercial re-use. See rights and permissions. Published by BMJ.

To cite: Angus-Leppan $\mathrm{H}$. Pract Neurol 2020;20:263264.
Dad aged 60 years was a powerhouseenergetic, handsome, tall and powerful. I thought he would live forever. He and mum were mountaineers, opening a treacherous climb in the Drakensberg, South Africa, which bears their name (figure 1), fleeing apartheid and starting a new life in Australia. He was a pioneering academic in his field after a terrible childhood. An exceptional marriage, three children, lots of adventures.

Then at 64 a colleague noticed that he looked a little stiff, and he was diagnosed with Parkinson's disease.

He kept falling-a dramatic plunge head first into a swimming pool at a posh party in his finest clothes, stumbles and trips on a bushwalk, multiple falls backwards from ladders. This was made all the more worrying as he was on warfarin for pulmonary emboli. His neck was really rigid and he didn't move his eyes.

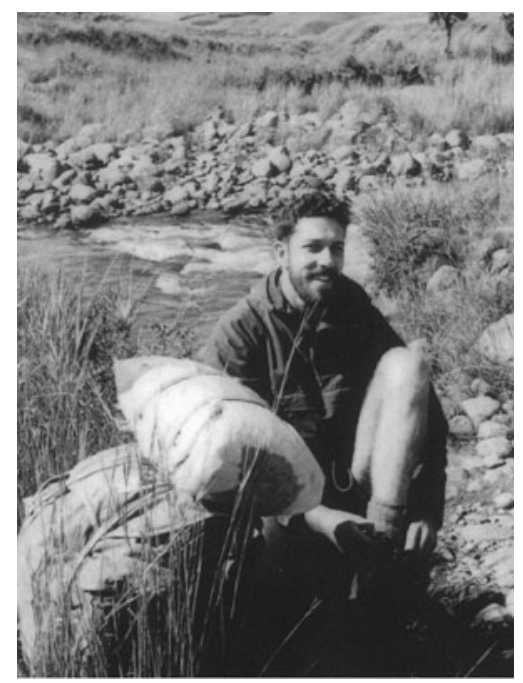

Figure 1 Peter Angus-Leppan in the foothills of the Drakensberg during a 2-week climbing trip in 1961 opening up new rock climbs on Champagne Castle and other peaks in Lesotho (then Basutoland). Photo by Pam Angus-Leppan (personal collection of Angus-Leppan) (item 1961-0301).
I realised this was progressive supranuclear palsy (PSP). I didn't want to tell him or the family; it seemed too awful to bear. Maybe my diagnosis was wrong. Maybe I should wait a bit. I didn't know how we could cope with this terrible disease.

He kept going. There were some twists in the tale. The early misdiagnosis helped him-he did have some response to levodopa and he may not have been offered this if he had been correctly diagnosed. Mum was incredible-against her bossy neurologist daughter's advice she kept him doing things. He went on buses to his volunteering-working for a charity promoting zero population growth (we chuckled at him having a daughter with four then five children) and he walked along the beachfront every day. He fell lots, bloodied his knees and sometimes his nose, but he kept going. Mum made him dress and wash himself every day even if it took an hour or more.

He didn't complain. Once, long after he had a percutaneous endoscopic gastrostomy (PEG) tube, and fluids caused him violent coughing, he said to me with a smile that he would really like a cup of tea, but he knew he couldn't. The blunting of his previously fine frontal cortex was a blessing. He didn't look in horror at what he had lost, or at what lay ahead.

And when things got worse, and he had nothing by mouth, he bonded over the PEG feeds, which his 5 year-old grandson often did for him. Dad was loved by his carers, who took him on walks and joked with him. Mum never hovered over them, she left them to it. As soon as they arrived, mum was off, grabbing an hour to do her own thing, to recharge her enthusiasm and her drive.

Dad walked his younger daughter down the aisle to be married, just months before he died. He cuddled his youngest granddaughter days before he died. 
Table 1 Learning points

\begin{tabular}{|c|c|c|}
\hline Key points & Comments & References \\
\hline $\begin{array}{l}\text { Raise the possibility of a Parkinsonian } \\
\text { syndrome if in doubt }\end{array}$ & Initial features may be subtle or equivocal & $\begin{array}{l}\text { Early descriptions and recent revisions emphasise the } \\
\text { variability of clinical features }{ }^{12}\end{array}$ \\
\hline $\begin{array}{l}\text { Offer a trial of levodopa to people } \\
\text { with PSP }\end{array}$ & Some people with PSP initially respond & $\begin{array}{l}\text { Response rate estimates vary from } 10 \% \text { to } 50 \% \text {; the PSP- } \\
\text { Parkinson's form has the highest levodopa response rate }{ }^{23}\end{array}$ \\
\hline $\begin{array}{l}\text { Dad seemed less distressed about his } \\
\text { condition than us, viewed by me as } \\
\text { 'blunting of his previously fine frontal } \\
\text { cortex' }\end{array}$ & $\begin{array}{l}\text { In fact, PSP is predominantly subcortical so } \\
\text { there may be apathy ('acceptance') or } \\
\text { frontal disinhibition } \\
\text { Responses will be slower so give PSP } \\
\text { patients time to express themselves }\end{array}$ & $\begin{array}{l}\text { Cognitive dysfunction occurs in most people with PSP } \\
\text { Executive function is the most affected involving subcortical/ } \\
\text { frontal connections } 45\end{array}$ \\
\hline $\begin{array}{l}\text { Medical relatives may seem angry or } \\
\text { interfering and adopt a healthcare } \\
\text { role, without having insight }\end{array}$ & $\begin{array}{l}\text { This is often due to fear and powerlessness } \\
\text { Guide us to stop trying to be our relative's } \\
\text { doctor or nurse }\end{array}$ & $\begin{array}{l}\text { There is general information for relatives of people who are } \\
\text { terminally ill and PSP associations worldwide that offer } \\
\text { support }^{67}\end{array}$ \\
\hline Excellent palliative care is crucial & $\begin{array}{l}\text { Compassionate end-of-life care has a major } \\
\text { impact } \\
\text { Resist cut-backs that threaten progress in } \\
\text { palliative care }\end{array}$ & $\begin{array}{l}\text { Worldwide, only 14\% of people who need palliative care } \\
\text { receive it }{ }^{8}\end{array}$ \\
\hline $\begin{array}{l}\text { Mum was sent a letter about dad's } \\
\text { histology results confirming PSP }\end{array}$ & $\begin{array}{l}\text { This could be distressing for some families, } \\
\text { particularly if the results are not as expected }\end{array}$ & $\begin{array}{l}\text { The UK Brain Bank information leaflet states that relatives will } \\
\text { be sent a letter with results } \\
\text { Best practice should include an offer for relatives to meet with } \\
\text { the treating clinician to discuss the results }\end{array}$ \\
\hline
\end{tabular}

PSP, progressive supranuclear palsy.

The final weeks were awful. There was an unremitting cough, which nothing seemed to settle. In the hospice I fought to hold on to him, until my little brother told me to stop trying to be dad's doctor, and just be his daughter. I cried tears of guilt and anger. Why did I live so far away, why hadn't I done more, maybe there's another treatment, maybe if he gets through this hurdle, he will have another few good months. But he didn't, and there wasn't another treatment, and in the end I thanked my brother.

We were all there when dad died and he was peaceful. His body was just a body, I couldn't get over that the life had left it.

Lots of people came to dad's cremation. And there was even humour, when the words of dad's favourite song, 'Bobby McGee' played at slightly the wrong time. His coffin slid through the final doors to 'Busted flat in Batin Rouge, headin' for the train'.

Dad donated his brain to research and the diagnosis of PSP was confirmed. Mum received a copy of the histology by mail-she wanted to see the report but it would probably have been better for this to be delivered in person (table 1). Fortunately it did not faze her. Mum cut down dad's trousers and wore them so she felt close to him.

And 9 months later dad's youngest grandson was born. We wished they could have met.

Contributors HA-L wrote the article and researched the box (in line with helpful suggestions from the reviewers).

Funding The authors have not declared a specific grant for this research from any funding agency in the public, commercial or not-for-profit sectors.

Competing interests None declared.
Patient consent for publication Next of kin consent obtained.

Provenance and peer review Not commissioned. Externally peer reviewed by Uma Nath, Sunderland, UK and Mark Lee, Sunderland, UK.

\section{ORCID iD}

Heather Angus-Leppan http://orcid.org/0000-0001-7004-3848

\section{REFERENCES}

1 Steele JC, Richardson JC, Olszewski J. Progressive supranuclear palsy. A heterogeneous degeneration involving the brain stem, basal ganglia and cerebellum with vertical gaze and pseudobulbar palsy, nuchal dystonia and dementia. Arch Neurol 1964;10:333-59.

2 Höglinger GU, Respondek G, Stamelou M, et al. Clinical diagnosis of progressive supranuclear palsy: the movement disorder Society criteria. Mov Disord 2017;32:853-64.

3 Ling H. Clinical approach to progressive supranuclear palsy. J Mov Disord 2016;9:3-13.

4 Gerstenecker A, Mast B, Duff K, et al. Executive dysfunction is the primary cognitive impairment in progressive supranuclear palsy. Arch Clin Neuropsychol 2013;28:104-13.

5 Houghton DJ, Litvan I. Unraveling progressive supranuclear palsy: from the bedsideback to the bench. Parkinsonism Relat Disord 2007;13:341-6.

6 What end of life care involves. Available: https://www.nhs.uk/ conditions/end-of-life-care/what-it-involves-and-when-it-starts/ [Accessed Dec 2019].

7 PSP associations throughout the world. Available: https://pspas sociation.org.uk/about-us/international-organisations/ [Accessed Dec 2019].

8 World Health Organisation. Palliative care. Available: https:// www.who.int/news-room/fact-sheets/detail/palliative-care [Accessed Dec 2019].

9 Parkinson's UK Brain Bank: answering your questions. Available: https://www.parkinsons.org.uk/sites/default/files/ 2019-02/PUKBB\%20Donor\%20Information\%20booklet\% 202018.pdf [Accessed Dec 2019]. 